\title{
ON THE MARGINAL COST OF WASTEWATER SERVICES
}

Steve H. Hanke

International Institute for Applied Systems Analysis, Laxenburg, Austria

Roland W. Wentworth

The Johns Hopkins University, Baltimore, Maryland, USA

RR-82-38

November 1982

Reprinted from Land Economics, volume 57, number 4 (1981)

INTERNATIONAL INSTITUTE FOR APPLIED SYSTEMS ANALYSIS

Laxenburg, Austria 
Research Reports, which record research conducted at IIASA, are independently reviewed before publication. However, the views and opinions they express are not necessarily those of the Institute or the National Member Organizations that support it.

Reprinted with permission from Steve H. Hanke and Roland W. Wentworth, On the Marginal Cost of Wastewater Services, Land Economics, 57(4):558-567.

Copyright (c) 1981 by the Board of Regents of the University of Wisconsin System.

All rights reserved. No part of this publication may be reproduced or transmitted in any form or by any means, electronic or mechanical, including photocopy, recording, or any information storage or retrieval system, without permission in writing from the copyright holder. 


\section{FOREWORD}

The French engineer, Jules Dupuit, published the classic article on costing and pricing in 1844 in the Annales des Ponts et Chaussées. Since then, there has been a considerable debate focused on the appropriate costing and pricing rules to be used by enterprises that operate in non-market environments. The literature associated with this debate has been primarily theoretical in nature and has covered both the cases of socialist enterprises operating in socialist economies (for example, Lange On the Economic Theory of Socialism, 1938) and public enterprises operating in capitalist economies (for example, Hotelling, The General Welfare in Relation to Problems of Taxation and Railway and Utility Rates Econometrica, 1939).

This article by Professor Hanke and Mr. Wentworth contributes to the debate on costing and pricing. By focusing, for the first time, on the costing and pricing of wastewater services, their article takes an important step beyond theory. It applies the rules of efficient resource allocation to a concrete example, so that practitioners have a guide that can be used in their determination of the marginal costs and design of tariffs for wastewater services. It should assist both socialist planners and the managers of public enterprises in capitalist economies in their attempts to apply the theory of efficient resource allocation to the real-world problems associated with the provision of wastewater services.

JANUSZ KINDLER Chairman

Resources and Environment Area 


\title{
On the Marginal Cost of Wastewater Services
}

\author{
Steve $\mathrm{H}$. Hanke and Roland W. Wentworth
}

The purpose of this paper is to analyze the marginal cost of municipal wastewater services. ${ }^{1}$ We begin by describing the nature of wastewater services. This is of importance since the measurement of marginal cost is an activity that requires a specialized knowledge of the engineering and technology of the industry (Turvey 1969). In the next section, we deal with the relevant definition and interpretation of marginal cost. We then apply our definition to the measurement of marginal cost for a hypothetical, but realistic, wastewater system. In the last section, we make some observations about the design of wastewater tariffs.

\section{ON THE NATURE OF WASTEWATER SYSTEMS $^{2}$}

Wastewater systems typically consist of facilities for the collection, pumping, transportation, treatment, and disposal of wastewater. Collection facilities or systems include building drains, street sewers or laterals, and appurtenant structures. Pumping facilities include pumping stations and pressurized lines (force mains) for the conveyance of wastewater, where the topography or hydraulic conditions preclude gravity flow. Transportation facilities include larger mains, known as interceptor sewers, and appurtenant structures which convey the wastewater from collection facilities to treatment facilities. The latter include various combinations of physical, chemi$\mathrm{cal}$, and biological processes designed to remove pollutants that are potentially hazardous to the public health, natural environment, or are aesthetically undesirable. Finally, disposal facilities are required for the ultimate disposal or reuse of the liquid and solid products of the treatment processes.

The planning of wastewater systems involves the determination of both the capacity of the various components and the timing of their construction. Because most of the structural components of wastewater systems exhibit significant economies of scale, it is generally economic to provide some amount of initial excess capacity in facilities whenever demand is growing over time.

The authors are, respectively, senior economist, President's Council of Economic Advisers, and graduate student, The Johns Hopkins University. Dr. Hanke is on leave from The Johns Hopkins University, where he is a professor of applied economics. They wish to acknowledge helpful comments on an earlier draft of this paper by D. Erlenkotter, J. Kindler, J. Niehans, and R. Turvey, and financial support from the International Institute for Applied Systems Analysis. An earlier version of this paper was produced as working paper WP- $80-167$ by the International Institute for Applied Systems Analysis A2361, Laxenburg, Austria.

${ }^{1}$ Although the marginal cost of water supply has been dealt with in this review by Turvey (1976), the literature does not contain analyses of the marginal cost of wastewater services. Our paper is written in much the same spirit as Turvey (1976) but has as a focus the unique problems of wastewater services. We should note also that the wastewater services we analyze are only those supplied by man. We do not, therefore, evaluate the marginal cost of using environmental waste assimilative capacity.

${ }^{2}$ For a more complete discussion of this subject, see: Clark and Viessman 1965; Fair, Geyer, and Okun 1966; and Metcalf and Eddy, Inc. 1972. Note that our analysis focuses exclusively on separate systems, since another approach must be used to evaluate the marginal costs of combined systems. 
Hydraulic considerations generally govern the design of collection, pumping, transportation, and disposal facilities. The design of treatment components is governed by the physical, chemical, and biological characteristics of the wastewater as well as its hydraulic, or flowrate, characteristics.

Collection facilities must have sufficient capacity to accommodate significant diurnal and seasonal variations due to groundwater infiltration. However, because street sewers must be constructed large enough to prevent clogging and facilitate maintenance, and be laid steep enough to prevent deposition of solids, the flow rate characteristics of discharged wastewater often do not determine the capacity requirements. This fact, and economies of scale dictate that collection facilities are normally constructed with sufficient initial capacity to convey the ultimate flows expected within the naturally tributary drainage area.

Pumping, transportation, and disposal facilities are subject to essentially the same design considerations as collection systems. However, there are major exceptions. For example, storage is often provided at pumping stations to reduce the required capacity of pumping units and force mains, items which otherwise would require sufficient capacity to meet instantaneous peaks. Also, transportation facilities, which serve larger and more diverse areas than do collection systems, benefit from the dampening effect that results from geographical and customer diversity. In addition, it is often feasible to stage the construction of transportation facilities, when the full development of the naturally tributary drainage area has not yet taken place.

Treatment facilities must be designed to accommodate varying flow rates and also to remove deleterious materials. Water pollution control laws often dictate the design parameters for treatment plants. Although the quantity of wastewater influent and effluent is not controlled by regulations, the quality or concentration of certain pollutants present in wastewater is usually controlled by pretreatment regulations for industrial influents and by effluent standards for treatment plant effluents.

One of the most common types of treatment facilities in use employs the activated sludge process. In this process, biologically active growths are maintained in continuous contact with organic waste, while in the presence of oxygen. The principal design parameters for this process are: (1) the maximum rate of wastewater flow; (2) the concentration of organic material in the wastewater, measured as biochemical oxygen demand (BOD); and (3) the concentration of suspended solids (SS).

An important characteristic of treatment facilities and their individual unit processes is that the water and its pollutants, which together constitute the wastewater influent, are treated together as joint products. For example, a primary sedimentation tank is part of an activated sludge treatment plant, and this tank accommodates the full volume of wastewater flow and removes a major portion of the influent suspended solids and a smaller portion of the influent BOD.

\section{ON THE RELEVANT CONCEPT OF MARGINAL COST $^{3}$}

The concept of marginal cost that we use depends on our objective. Our appli-

\footnotetext{
${ }^{3}$ Although there are a variety of methods that can be used to measure marginal costs (Saunders, Warford, and Mann 1977), we choose to follow Turvey (1976) and to
} 
cation of marginal cost information is for the design of tariffs for wastewater services. Our objective is to design these tariffs so that consumers are confronted with a signal that reflects the opportunity cost that their use of wastewater services imposes. Hence, we define the marginal cost of wastewater services so that it allows us to measure the opportunity cost of using these services. That is, in order to measure marginal cost, we measure the value of other products which the inputs, used to produce wastewater services, could have been used to produce.

To accomplish this task, we must not only possess a knowledge of the technology of wastewater systems, but also the demand and institutional characteristics for these services (Turvey 1969 and 1980). Two demand characteristics dictate, to a large degree, the concept of marginal cost that properly reflects the opportunity cost of using wastewater services. First, when demand for wastewater services is growing over time, this growth is generally the result of consumers' long-term decisions: consumers either choose to purchase durable equipment that uses water and generates wastewater, or, more importantly, they choose to reside in an area served by a municipal wastewater system. Therefore, consumers' decisions create what is perceived by the wastewater utility as permanent increases in the demand for wastewater services, and the utility develops its capacity expansion plan accordingly. Hence, the marginal cost concept that we adopt relates to these permanent increases. ${ }^{4}$

The second characteristic of wastewater demands concerns our lack of knowledge of price elasticities for wastewater use. ${ }^{5}$ To perform with precision, we must, in an iterative way, take into account the effect of demand on costs, of costs on prices, of prices on demand, etc., at each step of the planning process (Hanke 1978). However, without reliable price elasticity information, we cannot take these feedback effects into account simultaneously. Thus, the marginal cost we compute must be based on a given demand for wastewater services. Only as time passes can we observe reactions to price changes, revise our demand forecasts, and compute new marginal costs. This requires us to use a relatively long-term planning horizon for marginal cost analysis.

In addition to these demand characteristics, the cost to the wastewater authority and inconvenience to customers of rapidly changing tariff structures and levels also requires that we adopt a relatively long-term perspective for our cost analysis (Turvey 1971).

These technical and economic features of the wastewater industry make the standard, static, neoclassical cost analysis, with its distinction between shortand long-run costs, too simplistic to be

interpret and apply the concept originally presented by Turvey (1969). This is, in our opinion, the approach that has the greatest theoretical, as well as practical, appeal for the problems of wastewater services. [For a more extensive justification of Turvey's concept for the type of problem we analyze, see (Turvey 1980).]

${ }^{4}$ We should note that most of the literature on optimal pricing [an exception being (Turvey 1980)] adopts the assumption that price in the current period determines current demand. But, in the case of wastewater services, current demand depends to a large extent on consumers' own investment decisions with regard to water-using, wastewater-producing durable goods. These decisions are taken in light of, among other factors, a consumer's expectations about wastewater charges over a considerable number of years in the future. Since the only guidance that most consumers will have are the current charges, these charges must be based on a marginal cost concept that takes into account the opportunity costs of wastewater services over a rather extended time horizon. These facts dictate that we use Turvey's method for measuring marginal cost, since it incorporates a wastewater authority's "long-term" plans.

"For a review of the evidence on elasticities, see Seagraves (1978). 
useful. What is required is a dynamic cost analysis that incorporates time into both the output and pricing decisions (Turvey 1969).

A general definition of marginal cost, which allows us to estimate the opportunity cost of the use of wastewater services in dynamic terms, is straightforward. To estimate, for any year $y$, the marginal capital cost associated with a small permanent output increment starting in year $t$, where $t$ can equal $y$, we can compute the present worth of system capacity costs with the permanent increment starting in year $t$ and subtract from it the present worth of system capacity costs with output as planned, i.e., without the permanent increment. This difference is then divided by the size of the permanent increment in use, to obtain the marginal capital cost per unit of output. Hence, the marginal capital cost is a measure of the effect of use upon the total system costs, where the relevant total system costs include only those investments that are planned to satisfy increases in use or demand, and where the opportunity cost is measured in terms of a slowing down or a speeding up of the growth in use and associated investments. The marginal running cost per unit of output or use is added to the marginal capital cost, to yield a total marginal cost for each unit of output produced.

It should be recognized that the permanent output increment used to estimate marginal capacity costs represents nothing more than a convenient analytical device for estimating the marginal impact, brought about by a small permanent change in output occurring in year $t$, on the entire future time stream of costs. In a practical sense, we need simply to forecast the future growth (or decline) in the demand for wastewater services up to the end of the planning horizon, superimpose a small constant increment on this forecast, and then observe the change in present worth of the facilities planned to accommodate the original demand forecast. Thus, no restrictions are imposed on the shape of the demand forecast.

The economic interpretation of our definition of marginal cost is of particular interest. The definition and measurement of marginal running cost presents us with little difficulty. This results from the fact that the opportunity cost of output occurs at the same time that the output is produced. The marginal capital cost concept, however, is a different story. In this case, there is a displacement in time, between the time when a permanent increment in use or output occurs, and the time when its opportunity cost occurs. For example, when a permanent increment in use utilizes an increment of system capacity, there is often no need for immediate reduction in any alternative outputs, and no opportunity cost occurs at that time. However, resources that could be used to produce something else will eventually have to be used to produce system capacity sooner than originally planned. This represents the opportunity cost of adding a permanent increment to use today. Our marginal cost concept is designed to measure this "displaced" opportunity cost as of today, the time when the use that causes it occurs. Therefore, our concept allows us to measure "displaced" opportunity costs, so that we can set prices to signal consumers as to the opportunity costs that their current use imposes.

Another example will further illustrate our reasoning. The use of system capacity by a permanent increase in use is analogous to the use of an inventory of raw materials in a production process. If output or use occurs today, the opportu- 
nity cost of the use of the raw materials does not occur today. However, the use today results in the inventory having to be replenished sooner than planned. Hence, the use of the inventory today is not without its opportunity cost. It is this future or "displaced" opportunity cost that must be computed as of today-the time when it is caused-if prices of the goods produced are to reflect the real costs of the resources used to produce them. Our marginal cost concept is designed specifically for measuring these "displaced" opportunity costs.

We now use this general definition of marginal cost to develop an estimate of marginal cost for a hypothetical, but realistic, wastewater system.

\section{ON THE MEASUREMENT OF MARGINAL COST $^{6}$}

Consider a community of 300,000 people served by a single wastewater plant (Plant No. 1) of the activated sludge type, with a capacity to treat $570 \times$ $10^{3} \mathrm{M}^{3} /$ day (150 mgd) of wastewater flow, $71 \times 10^{3} \mathrm{~kg} /$ day $\left(157 \times 10^{3} \mathrm{lb} /\right.$ day $)$ of BOD and $57 \times 10^{3} \mathrm{~kg} /$ day $\left(126 \times 10^{3} \mathrm{lb} /\right.$ day $)$ of SS. At the present time, the average daily flow to the plant is $219 \times 10^{3} \mathrm{M}^{3} /$ day (58 mgd), the maximum daily flow (i.e., the flow rate relevant to the design of the treatment plant) is $438 \times 10^{3} \mathrm{M}^{3} /$ day (116 mgd), the average daily BOD load is $55 \times$ $10^{3} \mathrm{~kg} /$ day $\left(121 \times 10^{3} \mathrm{lb} /\right.$ day $)$, and the average daily SS load is $44 \times 10^{3} \mathrm{~kg} /$ day $\left(97 \times 10^{3} \mathrm{lb} /\right.$ day $)$.

We have completed a wastewater plan and have projected flows, loadings, and treatment capacity requirements over a 40-year period. Our projections (Table 1) indicate that annual wastewater flows will increase at a decreasing rate from 80 $\times 10^{6} \mathrm{M}^{3} / \mathrm{yr}\left(21 \times 10^{3} \mathrm{mgy}\right)$ in 1979 to 180 $\times 10^{6} \mathrm{M}^{3} / \mathrm{yr}\left(48 \times 10^{3} \mathrm{mgy}\right)$ in 2019 , and that BOD and SS loadings will increase in direct proportion to flows (i.e., the present concentrations of $250 \mathrm{mg} / \mathrm{l}$ and 200 $\mathrm{mg} / 1$ for BOD and SS, respectively, will remain unchanged).

The capacity expansion plan includes the construction of a new treatment facility (Plant No. 2), two expansions at the existing Plant No. 1, one expansion at Plant No. 2, a pumping station, a force main, and an interceptor sewer. The plan consists of four construction phases, with the completion of the Phase I projects in 1984. The three subsequent phases are expected to be completed in 1991, 1996, and 2004. The capacity provided for flow, BOD, and SS for specific facilities in each construction phase and their costs are presented in Table 2 .

Our expansion plan (Table 2) only includes components of the central system, since it is only these facilities whose capacity and timing are determined by changes in use parameters. Although other investments are planned (e.g., the expansion of the collection system, expenditures for routine replacement, and the upgrading of the quality of treatment of an old treatment plant), we do not include them in our plan, since they do not represent an opportunity cost of use.

To compute the marginal capital cost of 1979 use, the only use parameter that we are directly concerned with is flow. This results from the fact that our community is composed of domestic users and small businesses, and the metering of these consumers to measure their wastewater flows and BOD and SS

\footnotetext{
${ }^{6}$ The example in this section was developed by using information reported in Eckenfelder and Adams (1972); U.S. Environmental Protection Agency (EPA) (1978a); U.S. EPA (1978b); and U.S. EPA (1978c). It provides an illustration of the measurement of marginal cost for the case that most typically faces wastewater authorities.
} 
TABLE 1

The Projected Demand for Wastewater Services in Selected Years

\begin{tabular}{lccc}
\hline \multicolumn{3}{c}{ Projected Quantities } & \\
\hline Year & $\begin{array}{c}\text { Flow } \\
\left(10^{6} \mathbf{M}^{3} / \mathrm{yr}\right)\end{array}$ & $\begin{array}{c}\text { BOD } \\
\left(10^{\circ} \mathrm{kg} / \mathrm{yr}\right)\end{array}$ & $\begin{array}{c}\text { SS } \\
\left(10^{6} \mathrm{~kg} / \mathrm{yr}\right)\end{array}$ \\
\hline 1979 & 80 & 20.0 & 16.0 \\
1980 & 85 & 21.2 & 17.0 \\
1981 & 90 & 22.5 & 18.0 \\
1982 & 95 & 23.8 & 19.0 \\
1983 & 100 & 25.0 & 20.0 \\
1984 & 104 & 26.0 & 20.8 \\
1985 & 108 & 27.0 & 21.6 \\
1990 & 123 & 30.8 & 24.6 \\
1995 & 137 & 34.2 & 27.4 \\
2000 & 150 & 37.5 & 30.0 \\
2005 & 162 & 40.5 & 32.4 \\
2010 & 171 & 42.8 & 34.2 \\
2015 & 178 & 44.5 & 35.6 \\
2019 & 180 & 45.0 & 36.0 \\
\hline
\end{tabular}

TABLE 2

Capacity Expansion. Plan with Expected Flows and Loadings

\begin{tabular}{|c|c|c|c|c|}
\hline $\begin{array}{c}\text { Construction } \\
\text { Phase }\end{array}$ & Facility & Year & $\begin{array}{c}\text { Capacity } \\
\text { Increment }^{1}\end{array}$ & $\begin{array}{c}\text { Incremental } \\
\text { Cost }^{2}\end{array}$ \\
\hline \multirow[t]{2}{*}{ I } & $\begin{array}{l}\text { New secondary waste- } \\
\text { water treatment } \\
\text { facility (Plant No. 2) }\end{array}$ & 1984 & $\begin{array}{ll}\text { Flow: } & 120 \times 10^{3} \mathrm{M}^{3} / \text { day } \\
\text { BOD: } & 15 \times 10^{3} \mathrm{~kg} / \text { day } \\
\text { SS: } & 12 \times 10^{3} \mathrm{~kg} / \text { day }\end{array}$ & $\$ 30 \mathrm{M}$ \\
\hline & New interceptor sewer & 1984 & Flow: $150 \times 10^{3} \mathrm{M}^{3} /$ day & $\$ 3 \mathrm{M}$ \\
\hline II & $\begin{array}{l}\text { Secondary wastewater } \\
\text { treatment plant ex- } \\
\text { pansion (Plant No.1) }\end{array}$ & 1991 & $\begin{array}{ll}\text { Flow: } & 75 \times 10^{3} \mathrm{M}^{3} / \text { day } \\
\text { BOD: } & 9.4 \times 10^{3} \mathrm{~kg} / \text { day } \\
\text { SS: } & 7.5 \times 10^{3} \mathrm{~kg} / \text { day }\end{array}$ & $\$ 14 \mathrm{M}$ \\
\hline \multirow[t]{3}{*}{ III } & $\begin{array}{l}\text { Secondary wastewater } \\
\text { treatment plant ex- } \\
\text { pansion (Plant No.2) }\end{array}$ & 1996 & $\begin{array}{cc}\text { Flow: } & 110 \times 10^{3} \mathrm{M}^{3} / \text { day } \\
\text { BOD: } & 13.7 \times 10^{3} \mathrm{~kg} / \text { day } \\
\text { SS: } & 11 \times 10^{3} \mathrm{~kg} / \text { day }\end{array}$ & $\$ 18 \mathrm{M}$ \\
\hline & New pumping station & 1996 & Flow: $137 \times 10^{3} \mathrm{M}^{3} /$ day & $\$ 9 M$ \\
\hline & New force main & 1996 & Flow: $137 \times 10^{3} \mathrm{M}^{3} /$ day & $\$ 1.8 \mathrm{M}$ \\
\hline IV & $\begin{array}{l}\text { Secondary wastewater } \\
\text { treatment plant ex- } \\
\text { pansion (Plant No.1) }\end{array}$ & 2004 & $\begin{array}{ll}\text { Flow: } & 110 \times 10^{3} \mathrm{M}^{3} / \text { day } \\
\text { BOD: } & 13.7 \times 10^{3} \mathrm{~kg} / \text { day } \\
\text { SS: } & 11 \times 10^{3} \mathrm{~kg} / \text { day }\end{array}$ & $\$ 18 \mathrm{M}$ \\
\hline
\end{tabular}

${ }^{1}$ Treatment facilities are designed to provide capacity for maximum daily flow estimated to be equal to 2.0 times expected average daily flow at the end of the design period. Capacity is provided for BOD and SS, respectively, equal to the expected average daily loading at the end of the design period.

Interceptor sewers are designed to provide capacity for the peak hourly flow at the end of the design period estimated to be equal to 2.5 times the average daily flow.

2 All costs are expressed in terms of undiscounted 1979 dollars. 
TABLE $3^{1}$

Marginal Cost Calculations

\begin{tabular}{|c|c|c|c|c|c|}
\hline $\begin{array}{l}\text { Construction } \\
\text { Phase }\end{array}$ & Year & $\begin{array}{l}1979 \text { Present Worth }{ }^{2} \\
\text { of Investment with } \\
\text { Permanent Incre- } \\
\text { ment in Use }\end{array}$ & Year & $\begin{array}{l}1979 \text { Present Worth }{ }^{2} \\
\text { of Investment with- } \\
\text { out Permanent } \\
\text { Increment in Use }\end{array}$ & $\begin{array}{l}\text { Change in } \\
\text { Present } \\
\text { Worth }\end{array}$ \\
\hline I & 1983 & $\$ 22.54 \mathrm{M}$ & 1984 & $\$ 20.49 \mathrm{M}$ & $\$ 2.05 \mathrm{M}$ \\
\hline II & 1990 & $\$ 4.91 \mathrm{M}$ & 1991 & $\$ 4.46 \mathrm{M}$ & $\$ 0.45 \mathrm{M}$ \\
\hline III & 1995 & $\$ 6.27 \mathrm{M}$ & 1996 & $\$ 5.70 \mathrm{M}$ & $\$ 0.57 \mathrm{M}$ \\
\hline \multirow[t]{2}{*}{ IV } & 2000 & $\$ 1.83 \mathrm{M}$ & 2004 & $\$ 1.66 \mathrm{M}$ & $\$ 0.17 \mathrm{M}$ \\
\hline & & & & & $\$ 3.24 \mathrm{M}$ \\
\hline
\end{tabular}

(1) Total Change in 1979 Present Worth

(2) Permanent Increment in Use

(3) Marginal Capital Cost of 1979 Use $^{3}$

(4) Marginal Running Cost of 1979 Use $^{4}$

(5) Total Marginal Cost of 1979 Use $^{5}$

$$
\begin{aligned}
& =\$ 3.24 \times 10^{6} \\
& =6 \times 10^{6} \mathrm{M}^{3} / \mathrm{yr} . \\
& =(1) \div(2)=\$ 0.54 / \mathrm{M}^{3} / \mathrm{yr} . \\
& =\$ 0.03 / \mathrm{M}^{3} / \mathrm{yr} . \\
& =(3)+(4)=\$ 0.57 / \mathrm{M}^{3} / \mathrm{yr} .
\end{aligned}
$$

\footnotetext{
${ }^{1}$ For a similar analysis of the marginal cost of water supply, see Hanke (1981).

${ }^{2}$ Present worth is computed by using data from Table 1 and a discount rate of $10 \%$. For a recent estimate of the real rate of discount or opportunity cost of capital in the U.S.A., see Hanke and Anwyll (1980).

${ }^{3}$ This figure can also be interpreted in equivalent terms as an interest plus amortization charge, see Desrousseaux (1965) and Parmenter and Webb (1976).

${ }^{4}$ Computed on the basis of the following cost estimates: $\$ 0.014 / \mathrm{M}^{3} / \mathrm{yr}$., $\$ 0.045 / \mathrm{kg} / \mathrm{yr}$., and $\$ 0.028 / \mathrm{kg} / \mathrm{yr}$., for flow, BOD and SS, respectively, and at the concentrations mentioned in the text for a "composite unit" of use.

${ }^{5}$ The unit of use, measured in $\mathrm{M}^{3}$, incorporates use for BOD and SS represents a "composite unit" of use.
}

loadings is not economic. We are, therefore, limited to measuring their water use during periods when all the water they purchase is known to be returned to the wastewater system. This reading of water use (flow) is used as a measure of wastewater flow per period during these periods and as an estimate for the remaining periods in the year. Therefore, given that the concentrations of $\mathrm{BOD}$ and SS are constant among consumers and through time, flow is used to measure the use of the wastewater system in "composite units" (e.g., in units that include flow, BOD, and SS).

In 1979, we postulate a permanent increment in wastewater flows; that is, an increase above those we anticipated and used to plan our capacity expansion program. This permanent increment flow is 6 $\times 10^{6} \mathrm{M}^{3} / \mathrm{yr}$. Given that the concentrations of BOD and SS remain constant, the BOD and SS loadings increase by $1.5 \times$ $10^{6} \mathrm{~kg} / \mathrm{yr}$ and $1.2 \times 10^{6} \mathrm{~kg} / \mathrm{yr}$., respectively. These permanent increments were chosen such that they are equal to the expected growth in each parameter from 1983 to 1984 . Therefore, the permanent increment in use will cause existing capacity to be fully utilized exactly one year earlier than originally planned.

We are now ready to apply our definition of marginal cost to the measurement of marginal capital cost (see Table 3). We compute the present worth of system costs with and without the permanent increment in use, and then we compute their difference. The total change in present worths, or $\$ 3.24 \mathrm{M}$, is then divided by the permanent increment in use, or 6 $\times 10^{6} \mathrm{M}^{3} / \mathrm{yr}$., to yield a marginal capital cost of 1979 use of $\$ 0.54 / \mathrm{M}^{3} / \mathrm{yr}$. 
The total marginal cost for 1979 includes the marginal capital cost of $\$ 0.54 / \mathrm{M}^{3} / \mathrm{yr}$., and the marginal running cost of $\$ 0.03 / \mathrm{M}^{3} / \mathrm{yr}$. (See Table 3). It is equal to $\$ 0.57 / \mathrm{M}^{3} / \mathrm{yr}$. and represents, in real terms, the total marginal cost of a "composite unit" of use in 1979.

Before we conclude this section, it is important to emphasize that we cannot describe, in general terms, the effect that permanent increments in use will have on the optimal capacity expansion plan for any given community. In some cases, the plans for sequencing and designing facilities might have to be entirely reformulated, and in others, such as our example, the effect may be simply to bring forward in time each phase of the investment plan (Erlenkotter and Trippi 1976). However, our definition of marginal cost is general enough to be applicable for any situation in which a permanent increase in use is anticipated.

One situation merits special attention. It is the case in which a large industrial user moves into the community. If the industrial user plans to discharge units of wastewater into the system that differ greatly in character from the "composite units" of wastewater that we have utilized as the basis for our marginal cost calculations, then we must compute the difference in present worths between the wastewater system with and without the new industrial use. We must then divide the permanent increment in industrial use into the differences in present worths, to obtain a marginal capital cost. This marginal cost will probably be different from the one we have calculated, since the "composite units" of industrial use will differ from those in our example (e.g., the concentrations of BOD and SS will be greater). To obtain the total marginal cost for the industrial "composite units" of use, we must also compute marginal running costs, given the industrial concentrations of BOD and SS (see footnote 3 of Table 3). If the nature of the industrial wastes is constant throughout the year, it is economic to measure their wastewater flows and to set the price of a "composite unit" of their use equal to the total marginal cost for each industrial "composite unit" of use or flow (Turvey 1971).

In cases where industrial wastewater flows vary among industrial users and over time, it might become economic to abandon the "composite unit" of use concept and to monitor and price wastewater flows, and BOD and SS loadings separately. ${ }^{7}$ In these cases, it becomes necessary to measure the marginal costs of flow, BOD and SS separately. The marginal running cost causes little problem (see footnote 3 of Table 3). However, the marginal capital cost for each use parameter must be computed as a joint marginal cost (Marshall 1925 and Littlechild 1970), since the central system is jointly treating wastewater flow and BOD and SS loadings. ${ }^{8}$ We compute the

\footnotetext{
${ }^{7}$ We should caution that there are serious technological problems associated with continuous monitoring ("metering") of parameters such as BOD, and that the resources devoted to "metering" should be a function of the net benefits to be gained. Since these benefits are usually a function of the volume of wastes discharged, only the largest dischargers will warrant intensive wastewater monitoring (Baumol and Oates 1979, pp. 307-309). However, this does not diminish the importance of the price mechanism as a rationing tool for those users that do not warrant intensive monitoring. For example, a wastewater enterprise could adopt a schedule of "composite unit" charges (prices) and assign smaller dischargers to a specific price category based on their current discharge practices. Periodic reviews of discharge practices could then be made to determine if dischargers should be reassigned to another "composite unit" charge category. Such a procedure would contain an incentive for dischargers to reduce their discharges and a disincentive for them to increase discharges.

${ }^{8}$ We should note that in many situations the need for allocating joint costs does not exist. For most large treatment facilities, capacity can be expanded, at the margin,
} 
joint marginal costs by first computing the difference in the present worths of each component of the system with and without the permanent increment in industrial use. We must then allocate these differences to the three use parameters in proportion to the marginal benefits or relative demand that each places on each component of the system. These figures are then divided by the permanent increment in each use parameter, to yield a marginal capital cost per $\mathbf{M}^{3}$ per year for flow and a marginal capital cost per $\mathrm{kg}$ per year for BOD and SS. By adding the marginal running costs for each use parameter to their marginal capital costs, we obtain a total marginal cost for flow, BOD and SS.

\section{ON TARIFF POLICIES ${ }^{9}$}

In our judgment, the most efficient and administratively sound tariff structure for wastewater services is a two-part tariff (Coase 1946 and $\mathrm{Ng}$ and Weisser 1974). The first part of this tariff should be a price per "composite unit" of use. In our example, this price would be set at $\$ 0.57 / \mathrm{M}^{3} / \mathrm{yr}$. for 1979 . The second part of this tariff should be an annual standing charge per customer. The total amount of this standing charge should be equal to the total cost of system overheads that are not related directly to use, but must be covered to guarantee that the system is maintained ready for service over time.

Several points concerning the standing charges for individual customers or classes of customers are in order. First, many overheads can be traced directly to individual users. For example, metering and billing expenses as well as those associated with connecting customers to the system can be traced to individual customers and charged to them on an an- nual basis. Second, the remaining annual overheads can, in principle, be allocated to customers on the basis of their individual demands or consumer's surpluses. This task presents difficulties, given our knowledge of consumer demands. However, it is important to recognize the principle in question and to use it as a guide. Moreover, it is important to recognize that the benefits received (consumer's surpluses) most probably do not vary in direct proportion to consumers' physical characteristics (e.g., the size of water meters, the square footage of housing, number of baths, etc.), or to their use. These points underscore the importance of obtaining more reliable information on the nature of individual demands for wastewater services. However, they do not detract from the fact that economic efficiency and administrative efficacy could be attained by adopting two-part tariffs firmly anchored to the principle of marginal cost pricing.

for one parameter without expanding that for another. In these situations, separate and distinct marginal costs exist for each parameter, independent of any consideration of their relative demand intensities. This situation does not apply, however, for capacity in conveyance facilities (e.g., interceptor sewers) that always provide joint capacity at the margin.

${ }^{9}$ Although the demands for wastewater services and water supply are complementary, the analysis of the marginal costs of wastewater services and water supply should be conducted separately, since they are not joint products. However, one should realize that, due to this interrelationship of demands, it might be necessary to conduct marginal cost analyses of wastewater services and water supply at the same time and also design tariffs for both on a comprehensive and simultaneous basis. In this section, we choose not to do this, so that we can focus on the problem of immediate interest, i.e., wastewater services. In short, we shall proceed in our discussion of wastewater tariffs as if the water supply system that is a complement to our wastewater system has enough excess capacity to serve all demands over the planning horizon. Hence, the issues of analyzing the marginal cost of water supply and simultaneously designing wastewater and water supply tariffs is not relevant. 


\section{References}

Baumol, W. J. and Oates, W. E. 1979. Economics, Environmental Policy, and the Quality of Life. Englewood Cliffs, N.J.: Prentice-Hall, Inc.

Clark, J. W. and Viessman, W., Jr. 1965. Water Supply and Pollution Control. Scranton, $\mathrm{Pa}$.: International Textbook Company.

Coase, R. H. 1946. "The Marginal Cost Controversy." Economica. (Aug.)

Desrousseaux, J. 1965. L'Evolution Economique et le Comportement Industriel, Paris: Dunod.

Eckenfelder, W. W., Jr., and Adams, C. E., Jr. 1972. "Design and Economics of Joint Wastewater Treatment." Journal of the Sanitary Engineering Division, ASCE (Feb.).

Erlenkotter, D. and Trippi, R. R. 1976. "Optimal Investment Scheduling with Price-Sensitive Dynamic Demand." Management Science (Sept.).

Fair, G. M.; Geyer, J. C.; and Okun, D. A. 1966. Water and Wastewater Engineering. New York: John Wiley and Sons, Inc.

Hanke, S. H. 1978. "A Method of Integrating Engineering-Economic Planning." Journal of American Water Works Association (Sept.). and Anwyll, J. B. 1980. "On the Discount Rate Controversy." Public Policy (Spring).

1981. "On the Marginal Cost of Water Supply." Water Engineering and Management (Feb.).

Littlechild, S. C. 1970. "Marginal Cost Pricing with Joint Costs." The Economic Journal (June).

Marshall, A. 1925. Principles of Economics, Eighth Edition. London: Macmillan.
Metcalf and Eddy, Inc. 1972. Wastewater Engineering: Collection, Treatment, Disposal. New York: McGraw-Hill Book Company.

$\mathrm{Ng}, \mathrm{T}$. K. and Weisser, M. 1974. "Optimal Pricing with a Budget Constraint-The Case of the Two-part Tariff." The Review of Economic Studies (July).

Parmenter, B. R. and Webb, L. R. 1976. "Amortization and Public Pricing Policies." Australian Economic Papers (June).

Saunders, R. J.; Warford, J. J.; and Mann, P. C. 1977. "Alternative Concepts of Marginal Cost for Public Utility Pricing: Problems of Application in the Water Supply Sector." World Bank Staff Working Paper No. 259, May.

Seagraves, J. A. 1978. Guidelines for Efficient Use and Treatment of Water Pricing and Regulations. New York: The United Nations.

Turvey, R. 1969. "Marginal Cost." The Economic Journal (June).

- 1971. Economic Analysis and Public Enterprises. London: Allen and Unwin. 1976. "Analyzing the Marginal Cost of Water Supply." Land Economics (May). . 1980. "Long-Run Marginal Costs, ShortRun Marginal Costs and Optimal Pricing." Typescript (November).

U.S. Environmental Protection Agency. 1978a. Construction Costs for Municipal Wastewater Treatment Plants: 1973-1977. MCD-37, Washington (Jan.).

1978b. Construction Costs for Municipal Wastewater Conveyance Systems: 1973-1977. MCD-38, Washington (May). 1978c. Analysis of Operation and Maintenance Costs for Municipal Wastewater Treatment Systems, MCD-39, Washington (May). 

